\title{
Prevalence of Wax Moth in Modern Hive with Colonies in Kafta Humera
}

\author{
Etsay Kebede, Yisehak Tsegaye Redda*, Yohannes Hagos, Nesibu Awol Ababelgu \\ Mekelle University, College of Veterinary Medicine, Mekelle, Ethiopia \\ Email address: \\ etsaykebede@yahoo.com (E. Kebede),yistseg@yahoo.com (Y. T. Redda),yon1421@yahoo.com (Y. Hagos), \\ awolnesibu@gmail.com (N. A. Ababelgu)
}

\section{To cite this article:}

Etsay Kebede, Yisehak Tsegaye Redda, Yohannes Hagos, Nesibu Awol Ababelgu. Prevalence of Wax Moth in Modern Hive with Colonies in Kafta Humera. Animal and Veterinary Sciences. Vol. 3, No. 5, 2015, pp. 132-135. doi: 10.11648/j.avs.20150305.12

\begin{abstract}
A cross-sectional study was carried out from April 28 to May 30, 2009 in four village of Kafta Humera to determine the prevalence of wax moth in modern hive with colonies. A total of 307 modern bee hives with colonies were inspected during the study period. Physical inspection and observation were the methods of the study used. According to the study the overall prevalence of wax moth in modern bee hive was found to be $27.4 \%$. During the study period larval stage of wax-moth was only detected. The nature of severity was differentiated and categorized in to three groups as 35(11.4\%), $47(15.3 \%)$ and $2(0.65 \%)$ as light, moderate and severely affected respectively. Infestation rate of wax moth based on supering was found to have statistically significant difference as determined as $8(16 \%), 65(27.7 \%)$ and $11(47.7 \%)$ in base only, base plus one box and base plus two boxes. To combat the problem, awareness creation should be done on proper management of bee keeping in the area.
\end{abstract}

Keywords: Bee, Kafta Humera, Modern Hive, Wax Moth

\section{Introduction}

The contrasting geomorphic land scopes of Ethiopia create favorable environment for the existence of a large and unique biodiversity both in plants and animals including honey bee sub species. The ideal climate conditions and diversity of floral resources allow the country to sustain around 10 million honey bee colonies of which 7.5 million are kept in local bee hives around 30 thousand in top bar hives by farmers and the remaining exist in the forest as wild colonies. This makes the country to have the highest bee density in Africa [1,2,3].Beekeeping preserves nature, agriculture, sustains livelihoods, and provides food security [4]. Beekeeping in Tigray is most traditional and has long years of experience which is parallel to the history of agriculture, but still a recent time, Beekeeping and honey production for that matter has been in state of stagnation.

The honey bee could be affected by many infectious diseases which are parasites, bacteria, virus, protozoa, fungus, pests, and poisons and attacked by predators. Transmission of bee diseases from one colony to another can be by adult bee, reuse of contaminated comb, bee keepers, beekeeping equipment, feeding of infected honey and pollen $[5,6]$
Wax moths are potentially very troublesome to bee keepers all over the world. These are of two species of wax moth namely Galleria mellonnella and Achroing grisella. All occur naturally or have been introduced by man in almost all regions of the world. Wax moth is a serious destructive pest cause considerable damage to both normal and abandoned combs of bee and brings considerable loss to beekeeping industry [7].The weak colonies or abandoned combs are easily attacked more often by wax moth $[8,9]$. Throughout the world today they are an ever present cause of economic loss to bee keepers who have capital invested in framed combs built on comb foundation.

Wax moth emerge as adults in the hive and the female may live a few days or a few weeks after dark she flies out to a tree and mates, she then re-enters to hive and lays about 500 eggs. The newly hatched larvae can run very fast and thus distribute themselves around the hive, they then burrow in to comb, damaging it in a characteristics way by constructing a feeding tunnel of silk through it[10]. Damage may be done to combs containing honey to freshly extracted combs, and to stored combs. The market demand for beeswax both in the domestic and international trade is very high. Beeswax from Ethiopia has higher demand and also earns higher price in 
EU[11].The wax moth is also the major problem in the whole country and regions which causes damages and loses. Other than its presence the magnitude, type and amount of lose are not well studied in depth. Therefore the objective of this paper was to assess wax moth infection rate in modern bee hives in Kaft Humera district of Tigray.

\section{Materials and Methods}

\subsection{Study Area}

The study was conducted in Kafta Humera district ,Tigray regional state of Ethiopia. The study was conducted on four selected 'kebeles'/lockal administrative region / of the Kafta Humera district namely, Baecker, Adhrdi, Mayweyni and Adi-goshu. The geographical location of the research site is 13042 ' to $14028^{\prime}$ North latitude and 36023 ' to 370 31' East longitude and its elevation is $550-2800$ m.a.s.1. The mean monthly maximum temperature remains high throughout the year ranging from $30^{\circ} \mathrm{c}$ in August to $40^{\circ} \mathrm{c}$ in March and May in Humera.

\subsection{Study Design}

Across sectional epidemiological study was conducted from April 28 to June 30, 2009. During the study period data was collected through gross hive inspection of each hive. The data collected from the study area were summarized and analyzed by the possible categories and variables. The nature of severity was differentiated and categorized in to three groups as light, moderate and sever infestation based on the criteria of [12].

A total of 307 modern hives with colonies have been randomly sampled for wax moth infestation. Sample size taken for each study sites includes, Adhrdi from total 114 modern hives 50 were sampled; Baeker from 80 modern hives 36 were sampled; Adigoshu from 373 modern hives 163 were sampled and in Mayweyni from 130 modern hives 58 were randomly inspected $(44-45 \%$ of the total modern hives with colony in the selected village were included in the study).

\section{Results}

\subsection{Degree of Wax Moth Infection}

The total numbers of 307 modern bee hives with colonies were inspected during the study period. The routine internal inspection revealed that $27.4 \%(84)$ of the modern lives with colonies had visible larval stage of wax moth. Degree of severity based on Burges criteria was differentiated and categorized in to three groups as $35(11.4 \%), 47(15.3 \%)$ and $2(0.65 \%)$ light, moderate and severely affected respectively (Table 1).

Table 1. Categorical degree of wax moth infection in Modern hive.

\begin{tabular}{|c|c|c|c|c|c|c|}
\hline \multirow{2}{*}{ S.No. } & \multirow{2}{*}{ Village } & \multirow{2}{*}{ No of modern bee live inspected } & \multicolumn{3}{|l|}{ Degree of } & \multirow{2}{*}{ Total(\%) } \\
\hline & & & Light $(\%)$ & Moderate(\%) & Severe(\%) & \\
\hline 1 & Adhrdi & 50 & 5 & 16 & 2 & 23 \\
\hline 2 & Baecker & 36 & 2 & 14 & - & 16 \\
\hline 3 & Adigoshu & 163 & 22 & 10 & - & 32 \\
\hline 4 & Mayweyni & 58 & 6 & 7 & - & 13 \\
\hline Total & & 307 & $35(11.4 \%)$ & $47(15.3 \%)$ & $2(0.65 \%)$ & $84(27.4 \%)$ \\
\hline
\end{tabular}

During the study period egg and adult stage of wax moth were not detected.

\subsection{Comparison Based on Hive Positioning}

Out of 307 modern hive inspected 50(16.3\%), 234(76.2\%) and $23(7.5 \%)$ were base only, base plus one box and base plus two boxes respectively. The infection rate of wax moth based on their supering was determined as $8(16 \%), 65(27.7 \%)$ and $11(47.8 \%)$ in base only, base plus one box and base plus two boxes respectively (Table-2)

Table 2. Comparison between positioning of hives in wax moth infestation each study sites.

\begin{tabular}{|c|c|c|c|c|c|c|c|}
\hline \multirow[t]{3}{*}{ No } & \multirow[t]{3}{*}{ Sires } & \multicolumn{6}{|c|}{ Inspection of wax moth in each category } \\
\hline & & Base only & & Base plus one box & & Base plus two boxes & \\
\hline & & No of hive Inspected & + ve & No of hive Inspected & + ve & No of hive Inspected & $+\mathrm{ve}$ \\
\hline 1 & Adhrdi & 5 & 1 & 35 & 18 & 10 & 4 \\
\hline 2 & Adigoshu & 21 & 2 & 138 & 28 & 4 & 2 \\
\hline 3 & Baeker & 10 & 2 & 20 & 11 & 6 & 3 \\
\hline 4 & Maywyni & 14 & 3 & 41 & 8 & 3 & 2 \\
\hline Total & & 50 & $8(16 \%)$ & 234 & $65(27.7 \%)$ & 23 & $11(47.8 \%)$ \\
\hline
\end{tabular}

$\mathrm{X}^{2}=8.114 ; \mathrm{p}=0.017$

\section{Discussion}

An overall prevalence of wax moth in modern bee hive in the study area was found to be $27.4 \%$. The nature of severity was differentiated in to three categorized as light, moderate and severely affected. The larvae of was moth silken tunnels throughout the comb and when hives are heavily infested the combs are completely consumed and only the larval silk, droppings and cocoons remain in the hive [10]. Based on 
Burges criteria only $2(0.65 \%)$ from the total affected modern hives were severely affected. Based on positioning of hives the infection rate was determined in base only, base plus one box and base plus two boxes. The infection rate was statistically significant increasing as supering of hive increases and this current result is agreed with the idea of [11] as bee colonies become weak the chance of getting infection by wax moth is high and the combs are vulnerable to wax moth when in store, as well as inner parts of hives not occupied by bees. Supers of empty combs are sometimes left above the brood box for storage, but they are safe from wax moths only where the colony can be kept strong enough throughout the year [12].

The current result was indicating that infestation of wax moth in the study area was high. This may be due to the fact that lack of proper management in the study site. This can be due to lack of extension services in the district and lack of training to the farmers to create awareness about proper management. There is no method for killing of wax moth can take the place of management that prevents infestation in the hive $[13,14]$. The apiaries are to ensure that all colonies are strong and healthy. During the study period it was observed that larval stage of wax moth was responsible for destroying the combs. There for wax moth is mainly responsible for damaging the combs and feeds completely, and cause for the colony to be absconding. This is congruent to the idea of Crane [13] that combs are vulnerable to wax moth when in store as well as in parts of hives not occupied by bees. Estimated the annual loss in the USA as $\$ 500,000$ and the damage is likely to be relatively more in other parts of the world. The other important contribution for this higher wax moth infestation recorded in the area may be due to lack of food resources in the season and poor site selection. Weak colonies are easily susceptible to wax moth infestation. Burges[11]indicates that as adult wax moth emerge in the hive and the female may live a few days, in the hive a few weeks later she flies out to a tree and mates she then re-enters to hive and lays about 500 eggs in dark time in a weak colony.

\section{Conclusion and Recommendations}

The infestations of honey comb by wax moth are potentially very troublesome to bee keepers all over the world and the studied area. During the study period observation and inspection the combs were vulnerable to wax moth as in parts of hives not occupied by bees. The fast moving larval stage of wax moth was responsible in destroying the comb and its contents. It is must to keep colony of hive to be strong and healthy to avoid infestation of wax moth. In general we can conclude that poor management of bee keeping is the main reason for wax moth to invade modern bee hive. In light of the above facts the following recommendations can be made with respect to the status of the infestation of wax moth and then possible measures to be taken at the study area.

- awareness should be created to wards management of bees.
- Apiary inspectors, beekeepers and researchers must be able to recognize possible intervention, option that could improve on the control of wax moth.

- Site selection should be assisted by experts

- Flowering plants should be planted to increases bee forage

\section{References}

[1] Ayalew, K. (2001): promotion of beekeeping in rural sector of Ethiopia proceedings of the third National Annual conference of Ethiopia beekeepers Association (EBA) Septemeber 3-4 Addis Ababa, Ethiopia Pp 52-58.

[2] Nuru, A. (2002): Geographical races of honey bees of the northern regions of Ethiopia $\mathrm{PhD}$. Dissertation, Rhodes University, department of zoology and Entomology, South Africa Pp265.

[3] MOA, (2003): comprehensive honey and bees Was-marketing, 2nd draft, MOA, Addis Ababa, Ethiopia Pp 1-10.

[4] Tolera Kumsa Gemeda. Integrating Improved Beekeeping as Economic Incentive to Community Watershed Management: The Case of Sasiga and Sagure Districts in Oromiya Region, Ethiopia. Agriculture, Forestry and Fisheries. Vol. 3, No. 1, 2014, pp. 52-57. doi: 10.11648/j.aff.20140301.19

[5] DACA, (2006): Common Honey Bee Disease, Addis Ababa, Ethiopia Pp 402-420

[6] Morse. R.A. (1978): Honey bee pests, predators and diseases, USA Cornell University press Pp 430.

[7] Williams, J. L., (1976). Status of the greater wax moths, Galleria mellonella in the united states Beekeeping industry. Am. Bee. J. 166:11, 524 - 526.

[8] Kapil, R. P., Sihag R. C. (1983). Wax moth and its control. Indian Bee J. 45:47-49.

[9] Basavarajappa S. (2011). Study on the biological constraints of rock bee, Apis dorsata F. in southern Karnataka. UGC Major Research Project Report, New Delhi, India.

[10] Swamy, B. C., Rajagopal, D., Kencharaddi, R.N., (2005). Seasonal incidence of greater wax moth, Galleria mellonella in Indian Honeybee colonies. Ind. Bee J. 67:3\& 4, 176 - 181.

[11] Tolera Kumsa Gemeda. Integrating Improved Beekeeping as Economic Incentive to Community Watershed Management: The Case of Sasiga and Sagure Districts in Oromiya Region, Ethiopia. Agriculture, Forestry and Fisheries. Vol. 3, No. 1, 2014, pp. 52-57. doi: 10.11648/j.aff.20140301.19

[12] Burges, H.D. (1978): control of wax moth physical, chemical and biological methods, Bee world Pp 129-138.

[13] Johannsmeir, M.F.(2001): Beekeeping in South Africa "plant protection research institute Agricultural research council of South Africa" 3rd edition Pp 12-16, 198-220.

[14] Crane, E. (1990): Bees and bee keeping, science, practice and world resources, Heinemonn newness, Oxford, pp 614, 317350 .

[15] Amssalu et al, (2011) Management practices to prevent wax moth, a pest of honeybees HBRC, Holleta, Ethiopia. 
[16] Tolera Kumsa Gemeda. Integrating Improved Beekeeping as Economic Incentive to Community Watershed Management: The Case of Sasiga and Sagure Districts in Oromiya Region, Ethiopia. Agriculture, Forestry and Fisheries. Vol. 3, No. 1, 2014, pp. 52-57. doi: 10.11648/j.aff.20140301.19
[17] Gemechis Legesse Yadeta. Beeswax Production and Marketing in Ethiopia: Challenges in Value Chain. Agriculture,Forestry and Fisheries. Vol. 3, No. 6, 2014, pp. 447-451. doi: 10.11648/j.aff.20140306.12 